\title{
口腔扁平上皮癌の頸部後発転移に関する臨床病理学的研究
}

梅田正博・大森炤輝・横尾聡・寺延 治 中西孝一・島田桂吉

\section{A clinicopathological study of secondary neck metastasis of oral squamous cell carcinoma}

\author{
Masahiro UMedA - Akiteru OMORI - Satoshi Yokoo \\ Osamu Teranobu $\cdot$ Koichi Nakanishi Keikichi Shimada
}

\begin{abstract}
A clinicopathological study was made of 23 cases of oral squamous cell carcinoma with secondary metastasis to cervical lymph nodes, and the following findings were obtained.

1. Secondary lymph nodes metastasis appeared in $36 \%$ of No cases.

2. Clinical or histological factors (primary site, T-classification, age, treatment methods of primary tumor, degree of differentiation, mode of invasion, etc.) were not very available for the prediction of secondary metastasis.

3. The sites of metastasis were level I or level II in most cases.

4. The control rate of cervical tumor of secondary metastasis cases treated with radical neck dissection was $84 \%$, which is almost equal to that of first metastasis cases.

5. These findings suggest that elective neck dissection is not necessary for oral squamous cell carcinoma.
\end{abstract}

Key words: oral cancer (口腔瘦), secondary neck metastasis (後発湏部転移), elective neck dissection (予防的頸部部清)

I. 緒 言

口腔癌の治瘏成績向上のためには，原発策制御はもち ろん頸部リンバ節転移の制御が非常に重要である。特 に, 初䓂時 N0 で, 原発采治療後に頸部転移が出現す

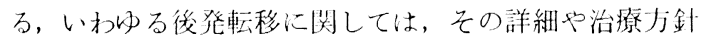
はいまだ決定していないのが現状である。そこで今团わ れわれは, 口腔粘膜扁平上皮癌の頸部後発転移症例の話

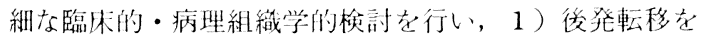
予测できる日子は存在するか，2）後登枟移症例の転移 様式と子後，3）予防的頸部利清の適心なとの，点につい て考察を加觉た。

神戸大学医学部口腔外科学教室

（主任：島田桂吉教授）

Department of Oral and Maxillofacial Surgery, Kobe University School of Medicinc (Chicf: Prof. Keikichi Shimada)

受付日：平成 2 年 9 月 3 日
II. 対象症例および方法

対象症例は1980 1989年までの10年間に神戸大学医学 部付属病院歯科口腔外科を受診した口腔粘膜俩平上皮癌 一次症例 205 例のうち, 頸部リンパ節に後発転移を認め た2 3 例である（表1）。後発転移の定我は, 初診時臨U 们に転移なしと判断されたが，経過中に原発宩がその時 点で制御されているのにかかわらナ钼部リンン節に転移 炎きたしたものとした。この23例のなかには、、゚の後

表 1 缜部リンパ節後発転移症例

\begin{tabular}{|c|c|c|c|c|c|}
\hline & $\mathrm{T} 1$ & $\mathrm{~T} 2$ & T3 & 'Г4 & it \\
\hline No & 10 & 10 & - & 1 & 21 \\
\hline N1 & - & 2 & - & - & 2 \\
\hline 計 & 10 & 12 & - & 1 & 23 \\
\hline
\end{tabular}

（神戸大学医学浬口腔外科 1980 1989年） 
表 2 原発巣の部位と後発転移の頻度

\begin{tabular}{lr}
\hline 原発部位 & 後発転移の頻度 \\
\hline 舌 & $11 / 29(37.9 \%)$ \\
下顎粎肉 & $4 / 12(33.3 \%)$ \\
上顎幽肉 & $2 / 11(18.2 \%)$ \\
口底 & $3 / 5(60.0 \%)$ \\
頓粘膜 & $0 / 1 \quad(0 \%)$ \\
口峓 & $1 / 1 \quad(100 \%)$ \\
計 & $21 / 59(35.6 \%)$ \\
\hline
\end{tabular}

* No 後発転移21例

表 3 原発栄の大きさと後発転移の頻度

\begin{tabular}{lr}
\hline $\mathrm{T}$ 分類 & 後発転移の頻度 \\
\hline $\mathrm{T} 1$ & $10 / 32(31.3 \%)$ \\
$\mathrm{T} 2$ & $10 / 21(47.6 \%)$ \\
early $\mathrm{T} 2(21 \sim 30 \mathrm{~mm})$ & $10 / 18(55.6 \%)$ \\
advanced $\mathrm{T} 2(31 \sim 40 \mathrm{~mm})$ & $0 / 3 \quad(0 \%)$ \\
$\mathrm{T} 3$ & $0 / 1 \quad(0 \%)$ \\
$\mathrm{T} 4$ & $1 / 5 \quad(20.0 \%)$ \\
計 & $21 / 59(35.6 \%)$ \\
\hline
\end{tabular}

* No 後発転移 21 例

発転移21例の他に，N1 で反刘側に後発転移をきたした 2 例が含まれている。各症例の臨床的・組織学的所見打 よび治療法と子後について众討した。

\section{III. 結}

果

\section{1. 後発転移の頻度}

No 症例の後発転移の瀕度について众討した。当科で は子防郭清は施行していないが，Noで原発巣のみ治療 され，原発采が制御でき，最低 6 か月以上経過している 59例中21例 (35.6\%) に後発枟移が出胃した。们位别て は上颚谏肉にやや少なかったものの, 特に差はなかった (表 2 ).

\section{2. $\mathbf{T}$ 分類と後発転移との関係}

上述の N0 症例59例の T分頪と後発枟移との關係につ いて検討した（表了）。T1 では 32例中10例 (31.3\%)， 21 30 mm の early-T2 ては18例中 9 例 $(50 \%), 31$ $40 \mathrm{~mm}$ の advanced-T2 および T3 では後軓枟移はみ

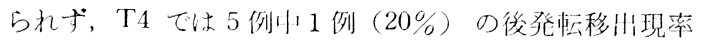
てあった。これらのよらによらに原発舁の大ささと後発

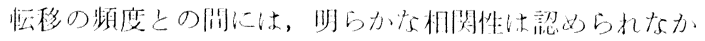
った。
表 4 年龄と後発枟移の頻度:

\begin{tabular}{|c|c|c|}
\hline \multicolumn{2}{|c|}{ 後発転移の有無 } & 年 齿 \\
\hline あり & 21例 & 39 83歳（平均64.5歳） \\
\hline なし & 38例 & 9 79歲（平均57.7歳） \\
\hline
\end{tabular}

* No 後発転移 21 例

表 5 治療法と後発転移の頻度

\begin{tabular}{c|c|c|c}
\hline & 組織内炤射 & 切除・他 & 計 \\
\hline 舌 & $8 / 22(36.4 \%)$ & $3 / 7(42.9 \%)$ & $11 / 29(37.9 \%)$ \\
口底 & $2 / 4(50.0 \%)$ & $1 / 1(100.0 \%)$ & $3 / 5(60.0 \%)$ \\
\hline 計 & $10 / 26(38.5 \%)$ & $4 / 8(50.0 \%)$ & $14 / 34(41.2 \%)$ \\
\hline
\end{tabular}

*舌. 口底癌34例

\section{3. 年齢と後発転移との関係}

No 症例59例を, 後発転移群 21 例と非転移群38例に分

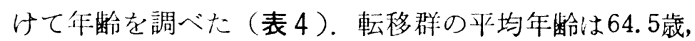
非転移群は57.7藏と転移群でやや高かったが，有意差は 涊められなかった。

\section{4. 治療法と後発転移との関係}

治療法, 特に組織内照射亡後発枟移との関係を検討し た。舌・口底癌 N0 症例34例について, 組織内照射を施 行した 26 例と, 口内法による舌部分切除なと（Laser surgery, cryosurgery b含む）去施行した 8 例に分けて， 後発転移の頻度を調べた（表 5 ）。組織内照射群では 26 例中10例 $(38.5 \%)$ ，切除群では 8 例中 4 例 $(50 \%)$ に 佾発枟移を認めて扣り，組織内照射が転移を促進すると いらよらな傾向はみられなかった。

\section{5. 原発巣の組織学的所見亡後発転移の頻度との関係} 原発栄の生検組織学的所見々後発枟移之の関係を検討 した。組織学的所見として，悪性度および浸潤様式の雨 者を检討した。恶性度は觕化度，異型性，核分裂像など により判定する WHO の基準1)を用い, grade-1（高分 化型), grade-2 (中分化型), grade-3 (低分化型) に分 楅した（写真１）。浸潤様式は，Jacobsson ${ }^{2)}$ や Willen ${ }^{3)}$ に隼して分類したが，grade-1は症例数も少なく grade-2 と本質的に同一之考えられるため，雨者を境界明瞙型 (W型）にまとめ, gradc-3 老中䦌型（M型），grade-4 をびょん性浸潤型（D型）とした（写真2).

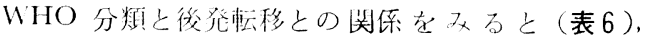

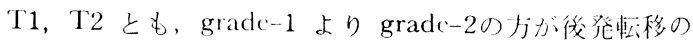
頻度が高かったが, grade-3 の症例は1例しかなく，後 炎枟移との阙連性は不明であった。

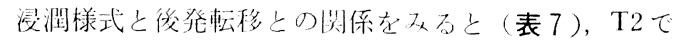

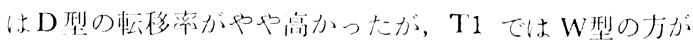

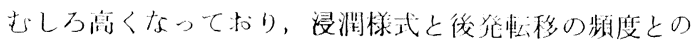




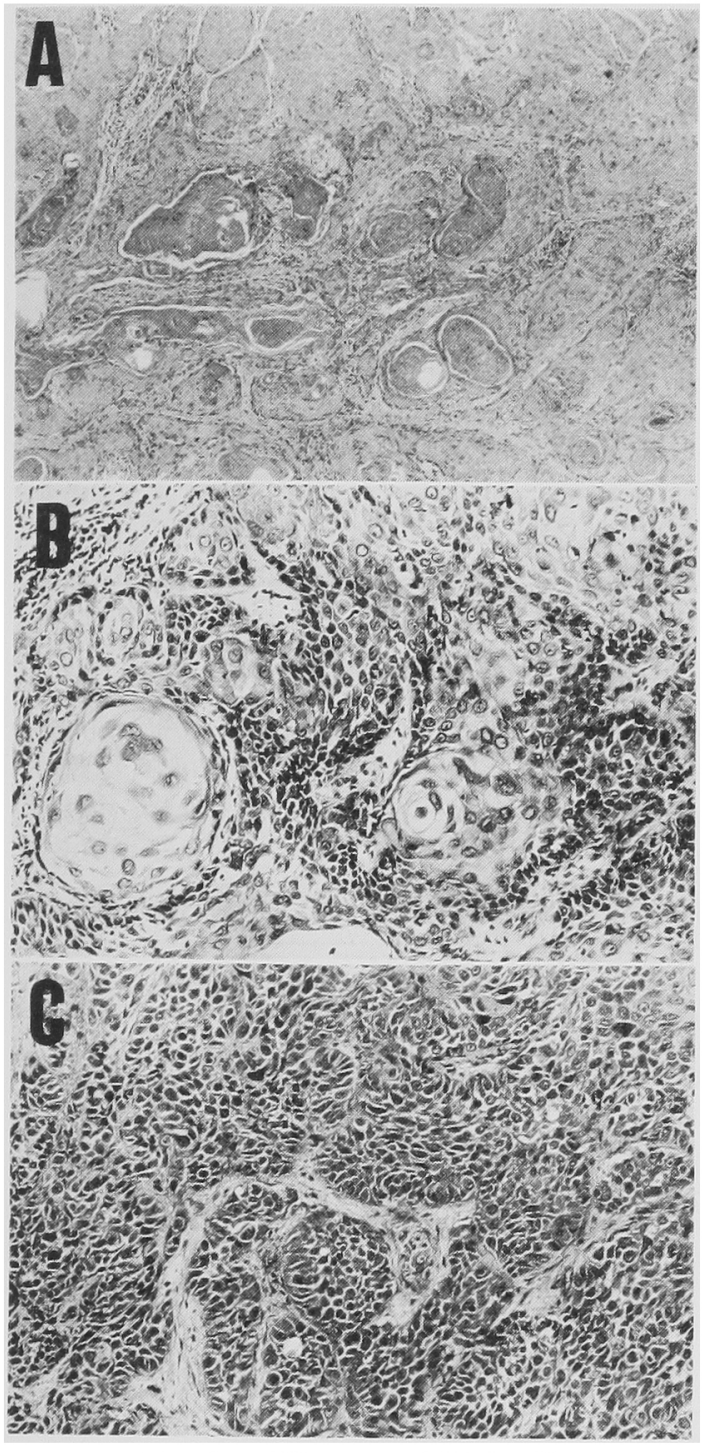

写真 1 WHO に上る悪性度分類

A：grade-1 (高分化型), B： grade-2 (中分化型),

$\mathrm{C}:$ grade-3（低分化型）

間には，明らかな関連性は認められなかった。

以上のように，原発巣の組織学的所見亡後発転移の頻 度との関連性を検討したところ，浸潤様式と後発転移と の間には関連性を認めなかったが，WHO 分類で grade2 の症例は, grade-1 に比べてやや後発転移が多かっ た.しかし，grade-1 であっても 4 例に 1 例の割合で後 発転䔟を生じていることを考えると，実際の臨床に特い ては，組織学的所見により後発転移の出現を予測するこ とはできないと思われた。

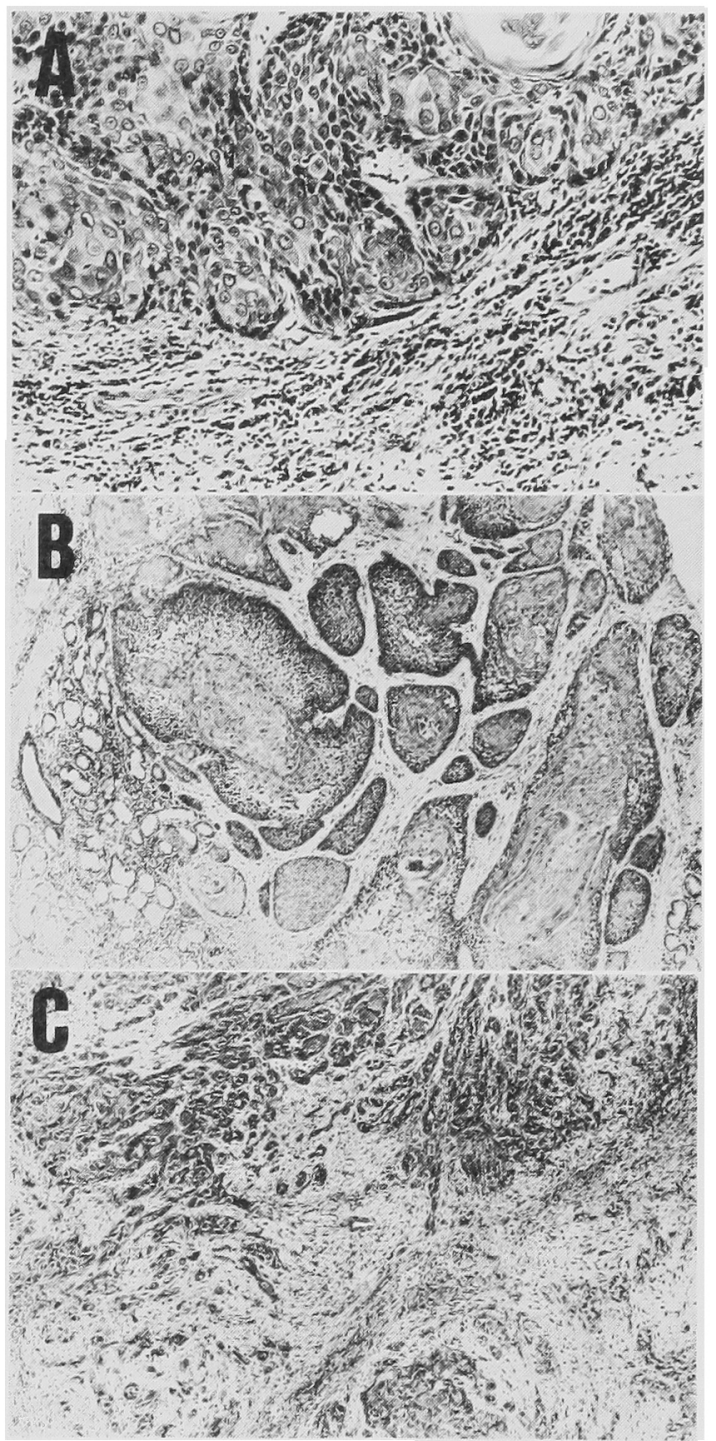

写真 2 浸潤棓式

$\mathrm{A}$ ：境界明瞕型 (W型)， $\mathrm{B}$ ：中間型 ( $\mathrm{M}$ 型), $\mathrm{C} ：$ びまん性浸潤型 (D 型)

\section{6. 転移様式}

後発転移症例の転移様式について検討した。転移出現 時期では，大部分は 1 年以内にみられた（表 8). 長期 間経過後の後発転移が 2 例あるが，これらはいずれも原 発栄再発症例で, 原発巣再手術 8 か月後, 13か月後に後 発転移をきたした症例である。

次に後発転移症例のらら頸部郭清を施行した20例につ いて組織学的に検討した. 表 9 は原発巣の部位と組織学 的転移部位との関係を示した（表 9）. 原発部位にかか わらず，汪とんどが level Iまたは level IIへの転移で 
表 $6 \mathrm{WHO}$ 分類と後発転移の頻度

\begin{tabular}{c|c|c|c|c|c}
\hline \multirow{2}{*}{$\mathrm{T}$ 分類 } & \multicolumn{4}{|c|}{ WHO 分類 } & \\
\cline { 2 - 6 } & grade-1 & grade-2 & grade-3 & 不 & \\
\hline $\mathrm{T} 1$ & $4 / 14(28.6 \%)$ & $5 / 11(45.5 \%)$ & - & $1 / 5(20 \%)$ & $10 / 30(30 \%)$ \\
$\mathrm{T} 2$ & $3 / 10(30 \%)$ & $7 / 11(63.6 \%)$ & - & $0 / 2(0 \%)$ & $10 / 23(43.5 \%)$ \\
$\mathrm{T} 3$ & $0 / 1(0 \%)$ & - & - & - & $0 / 1(0 \%)$ \\
$\mathrm{T} 4$ & $0 / 3(0 \%)$ & $1 / 1(100 \%)$ & $0 / 1(0 \%)$ & - & $1 / 5(20 \%)$ \\
\hline 計 & $7 / 28(25 \%)$ & $13 / 23(56.5 \%)$ & $0 / 1(0 \%)$ & $1 / 7(14.3 \%)$ & $21 / 59(35.6 \%)$ \\
\hline
\end{tabular}

*N0 後発転移 21 例

表 7 浸潤様式と後発転移の嚬度

\begin{tabular}{|c|c|c|c|c|c|}
\hline \multirow{2}{*}{$\mathrm{T}$ 分類 } & \multicolumn{4}{|c|}{ 浸潤様式 } & \multirow{2}{*}{ 計 } \\
\hline & W型 & M型 & $\mathrm{D}$ 型 & 不 明 & \\
\hline $\mathrm{T} 1$ & $5 / 14(35.7 \%)$ & $1 / 4(25.0 \%)$ & $2 / 7(28.6 \%)$ & $2 / 7(28.6 \%)$ & $10 / 32(31.3 \%)$ \\
\hline $\mathrm{T} 2$ & $5 / 11(45.5 \%)$ & $2 / 3(66.7 \%)$ & $3 / 4(75.0 \%)$ & $0 / 3(0 \%)$ & $10 / 21(47.6 \%)$ \\
\hline T3 & $0 / 1(0 \%)$ & - & - & - & $0 / 1(0 \%)$ \\
\hline $\mathrm{T} 4$ & $0 / 2(0 \%)$ & $0 / 1(0 \%)$ & - & $1 / 2(25.0 \%)$ & $1 / 5(20.0 \%)$ \\
\hline 計 & $10 / 28(35.7 \%)$ & $3 / 8(37.5 \%)$ & $5 / 11(45.5 \%)$ & $3 / 12(25.0 \%)$ & $21 / 59(35.6 \%)$ \\
\hline
\end{tabular}

*N0 後発転移 21 例

表 8 後発転移出現時期

\begin{tabular}{|c|c|}
\hline 時 期 & 症例 \\
\hline $1 \sim 3$ か月後 & 6 例 \\
\hline $4 \sim 6$ 加月後 & 8 例 \\
\hline $7 \sim 9$ か月後 & 4 例 \\
\hline $10 \sim 12$ か月後 & 2 例 \\
\hline 13〜15か月後 & 1 例 \\
\hline 34 か月後 & 1 例 $^{1}$ \\
\hline 65 か月後 & 1 例 $^{2}$ \\
\hline 計 & 23例 \\
\hline
\end{tabular}

1 原発柴再発より13か月後

2 原発栄再発上り 8 か月後

あったが, level IV への転移が1例にみられた。18例が 患側の転移であったが，口底癌で両側の level I に転移 がみられた症例が 1 例, 両側の level II に転移がみられ た症例が 1 例あった。

転移個数では，20例中 14 例は単発転移， 6 例が 2 個以 上の転移であった（表 10）。平均転移個数は 1.7 個であ り, これは当科に打ける同時期の初回転移 $\mathrm{pN}(+)$ 症例 の平均 2.5 個に比べると少なかった。一方節外浸鬥は後 発転移症例では転移リンパ節総数の $73.5 \%$ にみられ，初
表 9 組織学的転移部位

\begin{tabular}{|c|c|c|c|c|}
\hline & level I & level II & level III & level $\mathbb{V}$ \\
\hline 舌 & 3 & 5 & 0 & 1 \\
\hline 口底 & 2 & 2 & 0 & 0 \\
\hline 下㴿迷肉 & 1 & 2 & 0 & 0 \\
\hline 上顎迷肉 & 2 & 1 & 0 & 0 \\
\hline 口 咦 & 0 & 1 & 0 & 0 \\
\hline 計 & 8 & 11 & 0 & 1 \\
\hline
\end{tabular}

* 频部郭消施行症例20例

回転移症例の39.1\%に比べると高率であった。

原発巢の浸潤様式之転移巣の浸潤様式との一致性を検 討したが，原発巣の浸潤様式がW型・ $\mathrm{M}$ 型・D型のいず れにかかわらず，ほとんどの症例では転移策の浸潤様式 はD型を示し，両者の間には関連性は認められなかった （表11）.

原発巢の浸潤様式と転移部位, 転移個数との関係を表 12，13に示したが関連性は認められなかった。

次に,リンパ節の腫脹を認めてから頸部郭清を施行す るまでの期間と, 転移個数との関係を level I の転移と level II 以上の転移に分けて検討した（图 1). level I の後発車移では，手術時期はリンパ節を触知してから3 
表 10 組織学的転移個数

\begin{tabular}{cc}
\hline 転移湖数 & 症例 \\
\hline 1 㑬 & 14 例 \\
2 倜 & 2 例 \\
3 倜 & 1 例 \\
4 個 & 2 例 \\
5 個 & 1 例 \\
\hline
\end{tabular}

* 影部部消批行症例20例

(平均転移倜数 1.7 個)

表 11 原発采の浸潤应式と転移身の浸潤様式と の関係

\begin{tabular}{|c|c|c|c|c|}
\hline \multirow{2}{*}{ 原発㚌の浸潤様式 } & \multicolumn{4}{|c|}{ 転移果の浸潤様式 } \\
\hline & W型 & M型 & $\mathrm{D}$ 型 & 不明 \\
\hline W型 & & & 9 & 2 \\
\hline $\mathrm{M}$ 型 & & 1 & 2 & \\
\hline $\mathrm{D}$ 型 & & 1 & 1 & 1 \\
\hline 不明 & 2 & & 1 & \\
\hline
\end{tabular}

* 頙部郭清施行症例20例

表 12 浸潤様式と転移部位

\begin{tabular}{c|c|c|c|c}
\hline & level I & level II & level III & level IV \\
\hline W型 & 4 & 6 & & 1 \\
M型 & 1 & 2 & & \\
D型 & 1 & 2 & & \\
不明 & 2 & 1 & & \\
\hline
\end{tabular}

* 顓部郭清施行症例20例

表 13 浸潤様式と転移個数

\begin{tabular}{|c|c|c|c|c|c|}
\hline \multirow{2}{*}{ 浸潤様式 } & \multicolumn{5}{|c|}{ 転移䀦数 } \\
\hline & 1 倜 & 2 㑬 & 3 储 & 4 㑬 & 5 個 \\
\hline W & 8 & 1 & & 1 & 1 \\
\hline $\mathrm{M}$ & 1 & 1 & 1 & & \\
\hline $\mathrm{D}$ & 2 & & & 1 & \\
\hline 不明 & 3 & - & & & \\
\hline
\end{tabular}

*钼部部消施行症例20例

〜9週, 平均 6.3 週と, 比較的遅い症例が多かったが, ほとんどが単発転移であった。これに対し level II の後 発転移では， 2 例を除き $2 \sim 4$ 週後と比較的早期に頸部 剠清が施行されていたが，4週後に手術を行った症例で 为 7 例中 3 例で多発枟移が認められた。また11，13週後
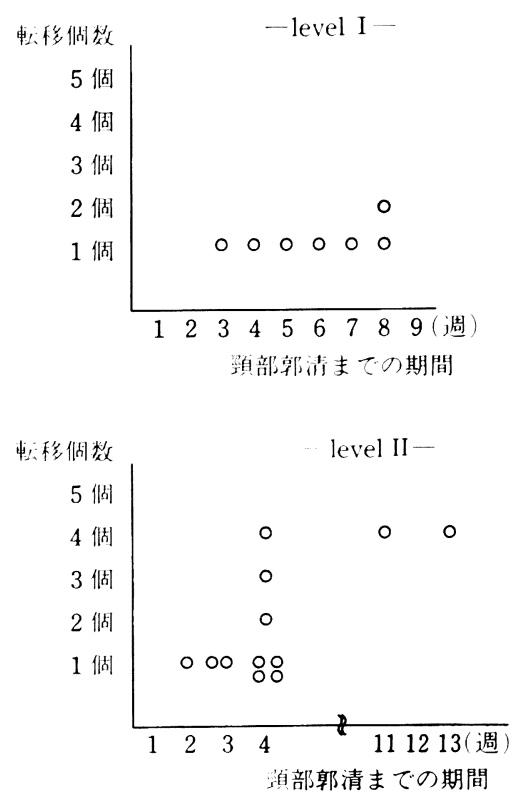

図 1 頙部郭消までの期間と転移個数

と頸部郭清が遅れた症例が 2 例あったが，これらは経過 観察が不十分であった症例で，いずれも多発転移を認め た。

\section{7. 治療法と矛後}

23例中頸部郭清が施行できたのは20例で，術式は片側 転移症例18例では全頸部郭清16例, 機能的全頸部郭清 1 例，舌骨上郭清 1 例と，ほぼ全例に全頸部郭清が施行さ れていた。機能的全頸部郭清と舌骨上郭清の症例は高跲 者で，䫟下リンパ節への後発転移症例であった。両側 level I 転移の 1 例では全頸部郭清十舌骨上郭清を同時 に, 両側 level II 車移の 1 例では 3 週の間隔で両側全頸 部郭清を施行した。また，術前化学療法や術前照射は原 則として行わず，できるだけ早期に頸部郭清を施行する ようにしているが，症例によっては手術までの期間に peplomycin が投与されていた。頸部郭清非施行の 3 例 は，高齿者で手術の同意が得られなかった症例で，1例 は非治療，2例に外照射が施行されたが，頸部の制御は できなかった。

頸部郭清群の経過㹥, 良好が16例, 頸部再発非制御が 3 例，原発笨再発非制御が 1 例であった（表 14）。経過 良好症例のなかには, 頸部郭清後, 原発栄のみに再発が 又られ原発巣再手術を施行し，経過良好である 3 例が含 まれている，結局後発転移症例で頸部剠清を施行した症 例の頸部制御率は, 原発栄再発非制御の 1 例を除き, 19 例中16例 $(84.2 \%)$ であった。一方，当科に招ける同時 期の初回転移症例で頸部剠清を施行した61例の頸部制御 率は，全症例で $91.5 \%, \mathrm{pN}(+)$ 症例に限ると $84.0 \%$ で 
ある（表15）。後発転移症例は全例 $\mathrm{pN}(+)$ であること 上り，初回転移も後発転移も注注同程度の制御率とい方 る.

図 2 は後発転移症例の累積生存率を示したもので, 頸 部郭清を施行した 20 例の 5 年生存率は $68 \%$ であった。こ れは初回転移で頸部郭清を施行した症例の $49 \%$ ，そのう ち $\mathrm{pN}(+)$ 症例の $39 \%$ と比較すると良好であったが（図 了), その理由は初回転移例ては原発巣非制御となる症 例が多かったためである。

\section{8. 頸部非制御症例の検討}

次に後発転移症例て頸部郭清を施行したが，頸部非制 御となった 3 例の特徵について述べる（表 16）。原発部 位では舌, 口底, 上靧霜肉が各 1 例で, 転移出現時期は 2，4，7 か月後であった。原発巣の浸潤様式はW型が 2 例, D型が 1 例で, WHO 分類では grade-1 が 1 例, grade-2 が 2 例と, 特に組織学的悪性度が高い症例はな かった。症例 1 と 2 はリンパ節の腫脹に気づいてから 4 週後に頸部郭清が施行されたが，いずれもリンパ節の增 大は速やかで，手術時には多発性かつ固着性（1978年 UICC 分類の N3) となっていた。 症例 3 は経過観察が 不十分で手術時期が遅れ，やはり多発性かつ固着性とな った症例である。

これらのよらに非制御症例は，原発部位や組織学的悪 性度には関係なく, level II 以上の転移で手術時にはすで

表 14 治療法と経過

\begin{tabular}{cclr}
\hline \multicolumn{2}{c}{ 治療法 } & \multicolumn{3}{c}{ 経 過 } \\
\hline 頸部郭清 & 20 例 & 良好 & 16 例 \\
& & $\mathrm{N}$ 非制御 & 3 例 \\
& & $\mathrm{T}$ 再発非制御 & 1 例 \\
& & $\mathrm{N}$ 非制御 & 2 例 \\
外照射 & 2 例 & $\mathrm{N}$ 非制御 & 1 例 \\
非治療 & 1 例 & & \\
\hline
\end{tabular}

表 15 頸部制御率

\begin{tabular}{cc}
\hline 転移時期 & 頸部制御率 \\
\hline 初回転移 (全症例) & $43 / 47(91.5 \%)$ \\
初回転移 $(\mathrm{pN}+$ 症例) & $21 / 25(84.0 \%)$ \\
後発耺移 (全例 $\mathrm{pN}+)$ & $16 / 19(84.2 \%)$ \\
\hline
\end{tabular}

に多発性, 固着性となっていた症例で, 後発転移の早期 発見・早期治療が重要であると思われた。

$$
\text { IV. 考察 }
$$

口腔癌の治療において, 原発巣の制御が重要であるこ とはもちろんであるが，近年では再建外科をはじめ各種 治療法の進歩に伴い, 原発巣制御率は飛躍的に向上し, 頸部転移巣の制御状態が予後を左右することも少なくな い。われわれは現在, 頸部転移に関する臨床病理学的検 討を進めているが，本稿では原発巣治療終了後に頸部転 移が出現する, いわゆる頸部後発転移症例について報告

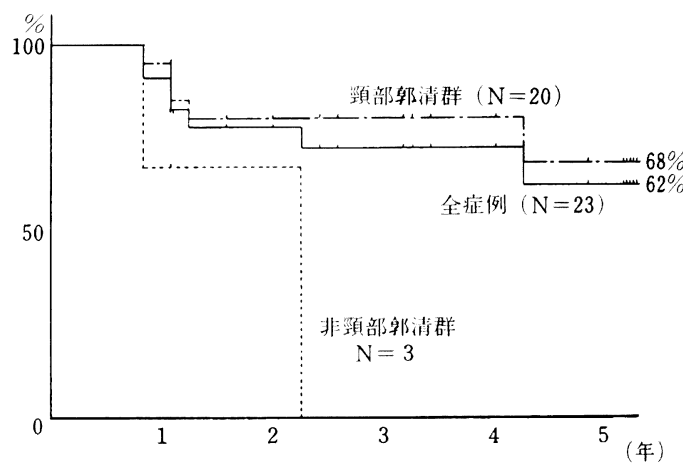

図 2 後発転移症例の累程生存率

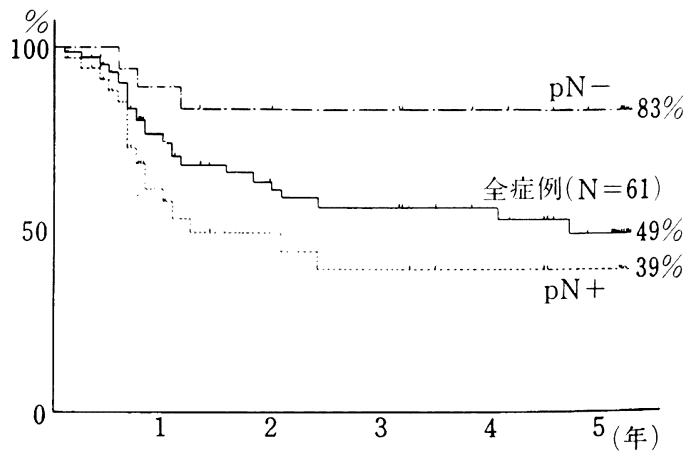

図 3 初回転移症例の累積生存率

表 16 頸部非制御症例

\begin{tabular}{|c|c|c|c|c|c|c|c|c|}
\hline 症例 & 原 発 & 転移時期 & 枟移部位 & 転移個数 & 撚着の有無 & WHO 分類 & 浸潤様式 & 手術時期 \\
\hline 1 & 上䫇稳肉 & 2 か月 & level II & 2 個 & $(+)$ & grade -2 & W型 & 4 週後 \\
\hline 2 & 口底 & 4 か月 & level II & 4 個 & $(+)$ & grade -2 & $\mathrm{D}$ 型 & 4 週後 \\
\hline 3 & 舌 & 7 か月 & level IV & 5 㑬 & $(+)$ & grade -1 & W型 & 13週後 \\
\hline
\end{tabular}


した。

後発転移についてこれ末では，1。初診時 N0 で原発 坚が制御された症例でも約16〜30\%に後発転移が出現す る，2，後発転移症例の予後は䄪 10 ～50\% と不良であ る，3，したがって症例によっては予防部清や予防照射 が必要であるなどの報告がなさ机てきた。また山本ら゙ は, 原発晕の浸洞様式がびまん性浸潤型の症例では後発 転移は高頻度でみられるため,このような症例では T1 であっても予防郭清を行らべきであると述べている。わ れわれは,これらの報告の結果もふま方, 当科に拈ける 後発転移症例に閂して詳練な榆討を行い, 治療法の再检 討を行った。

\section{1. 後発転移を予測できる因子は存在するか}

後発転移を予湘することができれば，治療上有用であ るため, 種々の因子と後発転移の頻度との関係について 検討した。

口腔癌あるい:舌癌 $\mathrm{N} 0$ 症例における頸部後発転移の 頻度は， $16.4 \%$ (山本ら ${ }^{4}$ ), $20 \%$ (三橋 5 ) $), 24.4 \%$ (斎 藤 $\left.5^{6)}\right), 25.4 \%$ (中村 $\left.5^{7)}\right), 27.5 \%$ (河边 $\left.{ }^{8}\right), 29.4 \%$ $\left(\mathrm{Ash}^{9}\right)$ ) $32.9 \%$ (中村 $\left.{ }^{10)}\right), 41.3 \%$ (天津 $\left.{ }^{111}\right), 42.0 \%$ $\left(\right.$ 堀 $\left.5^{12)}\right), 44.4 \%$ (西尾ら $\left.{ }^{13)}\right), 44.8 \%$ (矢島 $5^{14)}$ )な どの報告があるが，われわれの症例ではN0て原発巣が 制御できた 59 例小 21 例 $(35.6 \%)$ の後発転移率であっ た。これらの転移率の差は, 治療方法も一因であると考 えられる。すなわち山本ら文の報告では, 下顎柬肉癌, 口底癌, 頓粘膜癌, 口峡咽頭癌では, 原発巣切除時に level I あるいは level II の郭清を併せ行っているため, 後発転移の頻度は低くなっているものと考光られる。わ れわれの施設ではN0 症例に対する予防部清は行ってい ないため, 後発転移の頻度は若干高い。また原発部位別 では, 舌癌に多いとする報告もあるが, 当科の症例では 特に差は梁められなかった。

原発巣の大きさと後発転移の頻度との関係では, T1 よりT2 の方がやや転移率は高かったが有意差はなく, T1 でも $30 \%$ を越光る後発転移率を示し, 原発巣の大き さは後発転移を予测するのに有用とはい光なかった。山 本 $5^{4)}$, 中村 $5^{7)}$, 堀 $5^{12)}$ も後発転移症例では, 原発柴 の大きさとの関連性は認められなかったと述べている。 一方, 当科拈ける同時期の初回転移症例では, 転移の 頻度は原発策が大きくなるにつれて高くなることが確か められている. 後発転移症例て原発栄の大きさとの関連 性が不明瞭となる理由は明らかではないが，転移成立に は原発巣の大きさだけではなく、種々の因子が関わって いるものと思われる。

年粭と後発転移との関係では, 後発転移症例怔非転移 症例に比べて有意差はなかったもののやや年湛が高かっ た，高秢者で後発転移が多い理由として腫序免疫能の低 下が予想されるため, 最近の症例でリンパ球数, リン パ球サプセット、リンパ球幼若化反応，SUPS，IAPな
ど種々の免疫学的パラメーターを検討しているが, 症例 数も少なく今後の検討課题である.

縕織内照射症例では後発転移の頻度が高いとする報 告7)もあるため, 両者の関係を検討した。舌・底癌で 原発坚が小さく，切除を行っても機能障害がほとんど起 こらないと考光られる症例で，口内法による舌部分切除 や Laser surgery, cryosurgeryなどを施行した症例は 8 例あったが、これらの症例と組織内照射を施行した症例 との後発転移の頻度を比較したところ, 特に差は認めら れなかった。すなわち、組織内照射症例で後発転移をき たした症例は，治䅫により転移が引き起こされたのでは なく、初診時にすでに潜在性の転移が存在していたもの と思われた。

次に原発紧の組織学的所見と後発転移との関係を検討 した。最近, 組織学的悪性度と頸部転移との間には密接 な閣連性のあることが多くの報告で明らかにされてき $た^{3,10,15 \sim 17)}$ 後発転移に関する臨床病理学的研究はあま りなされていないが山本ら゙) は, 後発転移症例のほとん どは浸潤椂式がびまん性浸潤型（山本・小浜分類 $4 \mathrm{C} ・$ 4D 型)の症例であったと述へで拈り, 中村 ${ }^{10}$ 多舌癌放 射線治療症例の檢討で, Jacobsson の分類と後発転移の 頻度との間に関連性が認められたと述べている。われわ 九も初回転移症例に拈いては, 恶性度の高い, 症例やびま 几性浸潤型の症例は，1. 原発巣が小さくても頸部転移 の頻度が高い，2．早期より level II を越光た領域に転移 をきたすことがある，3）転移個数が多いなどの結果を 得ている (大森, 梅田ら, 第44回日本口腔科学会総会). しかし後発転移症例に打いては，WHO 分類と後発転移 との間にやや関連性を認めたものの, 浸潤様式と後発転 移との間には明瞭な関連性は認められなかった。後発転 移症例でこれら組織学的所見と後発転移との関連性が不 明暸となる理由は明らかではないが, 後発転移の成立に は腫璄の悪性度だけではなく, 種々の因子が複雑に関与 しているものと思われる。

以上の上らに今回の結果からは, 後発転移の予測沉有 用な因子をみいだすことはできなかった。

\section{2. 後発転移症例の転移様式と予後}

後発転移症例の治療成續は一般覀く，5年生存率は 10 50\%程度の報告が多い，後発転移症例の成績を初回 転移 p.N ( + 症例の成績と比べると, 初回 $40 \%$ : 後発 44 $\%$ (高田 ${ }^{18}$ ), 5 年累積生存率), 初回 $33 \%$ : 後発 $25 \%$ (中 村 $5^{7}$, 5 年絶対生存深), 初回 $40 \%$ : 後発 $36 \%$ (山本 $5^{4)}$, 判定時期不明), 初回 $54 \%$ : 後発 $14 \%$ (矢島 $5^{14)}$, 5 年累嫧生存率) と, 初回転移症例之同程度かやや悪い と報告されている。しかし今回のわれわれの検討症例で は, 頸部郭清を施行した症例の頸部制御率は $84 \%, 5$ 年 累稓生存率は68\%と比較的予後は良好で妿った。当科に おける同時期の初回転移 $\mathrm{pN}(+)$ 症例の頸部制御率は84 $\%, 5$ 年累䅡生存率は $39 \%$ で, 後発転移症例と初回転移 
症例とを比べると頸部制御率は同程度, 生存率は後発転 移症例の方が良好であった。生存率の差は初回転移症例 では, 原発巣再発非制御症例が多かったためである。

後発転移症例で頸部郭清施行後頸部再発非制御となっ た症例は 3 例であったが，これらはいずれも level II 以 上の転移で固着性であり, 転移個数も複数の症例であっ た。山本ら ${ }^{4)}$ は後発転移症例において, 原発巣の浸潤様 式と頸部転移巣のそれとは類似すること，転移栄の臨床 病理所見と転移栄制御の成否との間に密接な関連性が認 められることなどを報告している。 しかしわれわれの検 討では，原発尛の浸潤様式がW，M，D型のいずれであ っても, 転移巣ではD型を示すことが多く、また，原発 巣の浸潤様式と転移部位, 転移個数, 節外浸潤, 制御な どとの間にも関連性は認められなかった。われわれも初 回転移症例に执いては, 原発巣の浸潤様式や細胞悪性度 と頸部転移様式あるいは尒後との間に関連性を認めてい るが，後発転移症例でこれらの関連性が不明であったの は, 悪性度の特に高い症例は初回転移をきたしているこ とがほとんどで，後発転移症例はそれほど悪性度が高く なかったためと考觉られた。結局, 後発転移症例の子後 を左右する因子は，臨床的な転移巣進展度であり，転移 の早期発見・早期治療が最も重要であると思われた。

われわれは, 初回手術後約 2 年間は, 原則として 2 週 間ごとに経過観察を行い，後発転移が疑われた場合は可 及的に早く頸部郭清を行らようにしている.今回の検討 で, level I の転移は, リンハ節の增大に気ついてから手 術までの時期が少々遅れても非制御となる症例はなかっ たが, level II の転移は発見後 4 週目に手術を施行しても 非制御となる場合があった。これは level II の転移は早 期発見が難しいためと, level II の転移巣は進展すると内 頸動脈と癒着を起こし, 完全切除不能となるためと思わ れた。

山本ら4)の報告とわれわれの症例とを比較すると, 彼 らの後発転移症例12例中, 単発転移は 4 例, 多発転移が 8 例, 平均転移個数は4.3個，頸部制御率は5/12（42\%) に対し，われわれの20例では，単発転移が14例，多発転 移が 6 例，平均転移個数は 1.7 個，頸部制御率は $16 / 19$ (84\%) であった。一方, 初回転移症例を比較すると, 彼 らの平均転移個数 2.2 個, 頸部制御率 $87 \%$ に対し, われ われの症例では平均転移個数 2.5 個, 頸部制御率 $84 \%$ と ほとんど差はみられない。これらのよらに両施設の結果 を比較すると, 初回転移 $\mathrm{pN}(+)$ 症例の成績は同程度で あるが，後発転移症例の成績は大きく異なっている，初 回転移症例よりも, 継続的に経過観察を行っている後発 転移症例の方が，本来なら転移個数の少ないらちに発見 することができるはずであること，後発転移症例では転 移桇の急速な增大をみることがあること，転移に対する 化学療法や放射線療法はそれ汪ど有効でないこと ${ }^{19,20)}$, などを考えると, 後発転移症例に対しては, 彼らのよ5
に術前化学療法を施行するよりも，われわれのよらにた たちに手術を施行するという治療方針の方が妥当である と思われる。

\section{3. 予防的頸部郭清の適応}

從来より口腔癌, 特に舌癌に㧍计万予防郭清の適応に ついては賛否雨論があり，意見の一致をみていない7,11, 13,21 23). 子防郭清を推奖する根拠は, 1. 口腔癌, 特に舌 癌では不顕性転移の頻度が高い，2. 頸部郭清の為害性 は低い, 3. 後発転移症例の予後は転移 (一) 症例や初回 転移症例と比較して不良であるなどである。一力これに 対し，予防郭清を行らべきでないとする報告の根拠は， 1. 過半数の症例では不要な手術をすることになる， 2. 頸部郭清後に原発栄が再発した場合, 皮下転移や遠隔転 移を起こすことがある，3．啟重な経過観察で対処でき るなどである。また予防照射を行っている施設あある が24)，その効果に否定的な意見もある ${ }^{12)}$. 頝部に予防照 射を行うと, リンパ節の触診がしにくくなることがあ り、われわれは施行していない.

最近では，すべての症例に子防郭清を施行するのには 否定的な意見が多く，後発転移が一予测される症例に対し てのみ尒防郭清を施行すべきであるといら観点から， 後発転移の子测因子に関する研究がさかんになってき た ${ }^{4,10)}$. 山本ら ${ }^{4)}$ は, 前述のように浸潤と後発転移との 間には密接な関連があり, びまん性浸潤型, 特に山本・ 小浜分類 $4 \mathrm{D}$ 型の症例では, $\mathrm{T} 1$ であっても予防郭清を行 らべきであると主張している。 しかし今回のわれわれの 検討では, 初回転移と比べて後発転移では原発巣の組織 学的所見と転移との関連性は不明瞭となり, 後発転移を 子测できる因子をみいだすことはできなかった。

後発転移を予測することができない以上, 予防郭清の 適応症を設定することはできず，すべての症例で予防郭 清を行らか，すべての症例で行わないかの，いずれかの 議論となる. その际の判断基準となるのは, その施設に おける初回転移症例と後発転移症例の予後の比較, 寸な わら経過観察により後発転移症例を救命できるかどうか といら点であろら。これまでの報告では, 初回転移 $\mathrm{pN}$ (十) 症例と後発転移症例の生存率には差はみられない か, 後発転移症例の方がやや悪いとするものが多かっ た。初回転移症例では原発巣再発非制御となる症例が多 いのに対し, 後発転移症例は原発紧が一応制御され, そ の後に再発する症例は少ないこと, あるいは原発巣がそ の後に再発した症例は最初から除外している報告すある ことなどを考えると，これらの報告例の成績は満足でき るものではなく, 予防郭清を肯定する結果である. しか 乙当科の症例では, 初回転移 $\mathrm{pN}(+)$ 症例と後発転移症 例の治療成續を比較すると, 頸部制御摔はどちらも約 84 $\%$ で同程度，5年累積生存深は初回転移症例 $39 \%$ に対し て後発転移症例 $68 \%$, むしろ後発転移症例の方が良好 であった。このように当科の成䋶が良好であったのは， 
経過観察を十分に行っていたことと転移が疑われたら術 前治療なしにただちに手術を施行したことによるものと 思われた。しかし，手術時期が遅れ，頸部非制御とな り，反省させられる症例もあった。今後も当科では，子 防郭清は施行せず，㢢重な経過観察を行らといら治療方 針をとっていく定である。

\section{V. 結語}

今回当科に拈ける過去10年間の口腔粘膜洏平上皮癌一 次症例のうち，頸部リンパ節に後発転移をきたした23例 について, 臨床病理学的検討を行い以下の結果を得た。

1. N0 症例の $35.6 \%$ に後発転移を生じた

2. 原発部位, 原発巣の大きさ, 年齢, 治療法, 原発 巣の組織学的所見などと後発転移の頻度との関連性を検 討したが，WHO 分類と後発転移との間にやや関連性を 認めたものの，いずれの因子も後発転移を予測するのに それほど有用ではなかった。

3. 転移部位はほとんどが level I または level II で， 転移個数は平均 1.7 個と, 初回転移例と比べて少なく, 比較的早期に頸部郭清を施行できた症例が多かった。

4. 後発転移で頸部郭清を施行した症例の頸部制御率 は84\%，5年累積生存率は68\%であり，初回転移例之比 ベて頸部制御率は同程度，生存率は良好であった。

5. これらのことより No 症例に対しては, 予防郭清 は必要でなく钽重な経過観察で対処できるものと考兄ら れた。

\section{引用 文 献}

1) WHO: Histological typing of oral and oropharyngeal tumors. Geneva, 1971, p 17.

2) Jacobsson, P.A., Eneroth, C.M., et al.: Histological classification and grading of malignancy in carcinoma of the larynx. Acta Rad Ther Phy Bio 12: 1-8 1973.

3) Willen R., Nathanson, A., et al.: Squamous cell carcinoma of the gingiva. Acta Otolaryng 79: 146-154 1975.

4) 山本悦秀, 宮川明, 他：口腔粘膜癌切除後の 後発転移に阅与る検討。癌の臨床 35：815-824 1989.

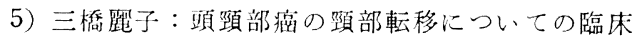
病理組織学的研究。日耳鼻 71：621-639 1968.

6) 斎藤利夫, 手島貞一, 他：口腔領域扁平上皮癌 の領域リンパ節転移に関する臨床統計的考察。 日口外誌 25：778-783 1979.

7) 中村社綱, 田代英雄, 他 : 口腔癌治療後の頚部 転移発症例について。日口外誌 25：68-72
1979.

8）河辺皒孝：頭頸部悪性腫場に扣ける三者合併療 法一舌癌に関して一日帛 72：585-588 1969.

9) Ash, C.L.: Oral cancer; A twenty five year study. Amer J Roentgenol 87: 417-430 1962.

10）中村太保：放射線治療成績よりみた舌癌の予後 因子と病理組織像との関連性について。阪大幽 学誌 31: 209-224 1986.

11）天津睦郎，井上健造：治療方針々その選択一手 術治療の立場から-. JOHNS 6: 213-216 1990.

12）堀信一, 井上俊彦, 重松康：舌痛 TXN0症 例の镍部リンパ節転移に関する検討。癌の臨床 23: 507-510 1977.

13）西尾正道, 桜井智康, 他 : 小線源治療を主体と した舌癌の放射線治療成績. 癌の臨床 32：3393441986 .

14）矢島幹人，崒村俊一，他：口腔扁平上皮癌以打 ける頸部郭清術施行例の臨床統計的検討。日口 外誌 35：647-654 1989.

15）新垣 晋：口腔領域悪性腫瘍の頸部リンパ節転 移に関する臨床病理学的研究。日口外誌 25 : 784-797 1979.

16）東富雄：口腔領域の扁平上皮癌に関与病理 組織学的研究。日口外誌 27：1337-1381 1981.

17) 山本悦秀, 宮川明, 他 - 口腔粘膜癌の所属り ン八節内浸潤增殖像に関する研究一特に原発采 の腫瘍の浸潤様式との関連について一。 日口外 誌 30: 1824-1833 1984.

18）高田和彰, 遠藤邦彦, 他：口腔領域悪性腫場の 頸部リンパ節転移に関する臨床統計的検討。日 口外誌 34:872-878 1988.

19）大関 悟：口腔粘膜扁平上皮癌に対するBleomycin の効果 第 1 編 Bleomycin 衍前投与の 意義に関する臨床的ならびに病理組織学的研究. 口科誌 30：206-237 1981.

20）山本悦秀，宮川明，他：口腔粘膜癌の镇部り ンパ節転移とその Bleomycin 感受性。日口外 誌 30：1805-1813 1984.

21）松浦 鎮, 牧野総太郎, 他：舌癌の Radium 針 を主軸とした集学治療。耳奥臨床 77：658-665 1984.

22) Nahum, A.M., Bone, R.C., Davidson, T.M.: The case for elective prophylactic neck dissection. Laryngoscope 84: 588-599 1977.

23）沁木修二：予防的頸部郭清術の適応。医学のお ゆみ 103：567-568 1877.

24) Million, R.P.: Elective neck irradiation for TXNO squamous cell carcinoma of the oral tongue and floor of mouth. Cancer 34: 1491551974. 